\title{
RETROSPECTIVA DA DISCUSSÃO SOBRE A AUTONOMIA UNIVERSITÁRIA*
}

Para a reflexão sobre a autonomia universitária trazemos a síntese bem elaborada pela ANDIFES**.

1994 - No último ano do governo Itamar Franco, é constituído um núcleo de trabalho, através de portaria ministerial, integrado pela SESu/MEC, Andifes, Andes, Fasubra e UNE, que produz um documento denominado Agenda Autonomia 94, com o objetivo de efetivar o exercício da autonomia universitária sem a necessidade de grandes modificações no ordenamento jurídico.

1995 - No primeiro ano do governo Fernando Henrique, a Andifes inicia contatos com o ministro da Educação, Paulo Renato Souza, para retomar a discussão. O governo encaminha ao Congresso o Projeto de Emenda Constitucional nํㅜㄹ, pela qual a autonomia prevista no artigo 207 da Constituição Federal seria regulamentada "na forma de lei". O expediente provoca enorme reação de todas as entidades, pois entendiam que o artigo 207 da Constituição dispensava qualquer tipo de regulamentação. O governo desiste da emenda.

1996 - Após dois anos de debate, a Andifes aprova a proposta de lei orgânica para a autonomia universitária. $\mathrm{O}$ projeto prevê a criação de um sistema de instituições federais de ensino superior; um Conselho Superior, composto por representantes das universidades públicas federais, representantes do poder Executivo, indicados pelo presidente da República, da comunidade científica, e do órgão colegiado normativo do poder executivo federal responsável pela formulação e acompanhamento da política educacional, hoje o Conselho Nacional de Educação. Define o regime jurídico próprio para a IFES; planos de carreira únicos, respectivamente para professores e servidores técnico-administrativos; o financiamento com base na subvinculação constitucional; e a distribuição desses recursos mediante critérios estritamente acadêmicos.

1996 - O governo encaminha o Projeto de Emenda Constitucional no370, que propõe a criação de um fundo para a manutenção e desenvolvimento do ensino superior público, constituído de $75 \%$ dos $18 \%$ de que trata 0 artigo 212 da Constituição, abrangendo instituições públicas federais, estaduais e municipais. A Andifes, desde o primeiro momento, propunha a criação desse fundo com "no mínimo" 75\% dos 18\% para as instituições federais.

** ANDIFES - Associação Nacional de Dirigentes das Instiuições Federais de Ensino Superior. 
1997 - O governo manda ao Congresso uma segunda versão da PEC nํㅜㄱㅣ, em que era suprimida a expressão público em relação à responsabilidade de manutenção e desenvolvimento do ensino superior, ampliando a destinação de recursos para além das universidades públicas, alcançando as particulares. A segunda versão foi lida na Comissão Especial da Câmara dos Deputados no dia 9 de setembro de 1997 e aí empacou.

1998 - Com a aprovação da reforma administrativa e da reforma previdenciária, o governo passa a considerar a possibilidade de regulamentar a autonomia através de um projeto de lei ordinária.

1999 - Em maio, o MEC divulga as suas "diretrizes para a autonomia". Em julho, lança o anteprojeto de lei que prevê a liberação de recursos para as universidades através de um contrato de gestão, uma subvenção econômica baseada no orçamento de 1997, regime de trabalho para professores e técnico-administrativos baseado na CLT e um estrito controle do Ministério do Planejamento, Orçamento e Gestão. No aspecto financeiro não é atendida a reivindicação de subvinculação, para o ensino público federal, de $75 \%$ dos recursos constitucionalmente assegurados para a educação.

1999 - Em julho, a Andifes articula a criação da Frente Parlamentar em Defesa da Universidade Pública no Congresso, com 150 deputados federais e 15 senadores. Ainda naquele mês aprova no seu Conselho Pleno o documento Fundamentos para a Autonomia Universitária, em que expõe as bases para o entendimento com o governo. O sindicato dos docentes e dos técnico-administrativos pedem ao MEC que não envie o projeto ao Congresso. Em agosto a Andifes entrega ao secretário de Educação Superior do MEC documento elaborado pelo seu Diretório Nacional afirmando que o anteprojeto de autonomia do governo impede a efetivação do princípio constitucional, concedendo "autonomia parcial e tutelada".

2000 - Em abril, o MEC institui grupo de trabalho com a finalidade de propor a regulamentação da contratação de um novo quadro de servidores celetistas para a universidade. Em julho, o governo divulga pré-projeto de lei propondo a regulamentação do emprego público e a elaboração de carreiras para docentes e técnico-administrativos das universidades federais, sob o regime da CLT. A Andifes divulga uma resolução reiterando sua posição no sentido de que a carreira dos docentes dos quadros permanentes das instituições federais de ensino superior deve ser considerada dentre as integrantes do Estado Nacional, ou seja, como carreira de estado, com direito à estabilidade. 